\title{
Evaluation of Sand Filtration and Activated Carbon Adsorption for the Post-Treatment of a Secondary Biologically-Treated Fungicide-Containing Wastewater from Fruit-Packing Industries
}

\author{
Konstantinos Azis ${ }^{1}$, Zografina Mavriou ${ }^{1}$, Dimitrios G. Karpouzas ${ }^{2} \mathbb{D}$, Spyridon Ntougias ${ }^{1, *(\mathbb{D})}$ \\ and Paraschos Melidis ${ }^{1, *}$ \\ 1 Laboratory of Wastewater Management and Treatment Technologies, Department of \\ Environmental Engineering, Democritus University of Thrace, Vas. Sofias 12, 67132 Xanthi, Greece; \\ kazis@env.duth.gr (K.A.); zmavriou@env.duth.gr (Z.M.) \\ 2 Laboratory of Plant and Environmental Biotechnology, Department of Biochemistry and Biotechnology, \\ University of Thessaly, Viopolis, 41500 Larissa, Greece; dkarpouzas@bio.uth.gr \\ * Correspondence: sntougia@env.duth.gr (S.N.); pmelidis@env.duth.gr (P.M.); \\ Tel.: +30-2541079313 (S.N.); +30-2541079372 (P.M.)
}

Citation: Azis, K.; Mavriou, Z.; Karpouzas, D.G.; Ntougias, S.; Melidis, P. Evaluation of Sand Filtration and Activated Carbon Adsorption for the Post-Treatment of a Secondary Biologically-Treated Fungicide-Containing Wastewater from Fruit-Packing Industries. Processes 2021, 9, 1223. https:// doi.org/10.3390/pr9071223

Academic Editors: Kostas A. Matis and George Z. Kyzas

Received: 7 June 2021

Accepted: 12 July 2021

Published: 15 July 2021

Publisher's Note: MDPI stays neutral with regard to jurisdictional claims in published maps and institutional affiliations.

Copyright: (c) 2021 by the authors. Licensee MDPI, Basel, Switzerland. This article is an open access article distributed under the terms and conditions of the Creative Commons Attribution (CC BY) license (https:// creativecommons.org/licenses/by/ $4.0 /)$

\begin{abstract}
In this work, a sand filtration-activated carbon adsorption system was evaluated to remove the fungicide content of a biologically treated effluent. The purification process was mainly carried out in the activated carbon column, while sand filtration slightly contributed to the improvement of the pollutant parameters. The tertiary treatment system, which operated under the batch mode for 25 bed volumes, resulted in total and soluble COD removal efficiencies of $76.5 \pm 1.5 \%$ and $88.2 \pm 1.3 \%$, respectively, detecting total COD concentrations below $50 \mathrm{mg} / \mathrm{L}$ in the permeate of the activated carbon column. A significant $\mathrm{pH}$ increase and a respective electrical conductivity (EC) decrease also occurred after activated carbon adsorption. The total and ammonium nitrogen significantly decreased, with determined concentrations of $2.44 \pm 0.02 \mathrm{mg} / \mathrm{L}$ and $0.93 \pm 0.19 \mathrm{mg} / \mathrm{L}$, respectively, in the activated carbon permeate. Despite that, the initial imazalil concentration was greater than that of the fludioxonil in the biologically treated effluent (i.e., $41.26 \pm 0.04 \mathrm{mg} / \mathrm{L}$ versus $7.35 \pm 0.43 \mathrm{mg} / \mathrm{L}$, respectively). The imazalil was completely removed after activated carbon adsorption, while a residual concentration of fludioxonil was detected. Activated carbon treatment significantly detoxified the biologically treated fungicide-containing effluent, increasing the germination index by $47 \%$ in the undiluted wastewater or by $68 \%$ after $1: 1 v / v$ dilution.
\end{abstract}

Keywords: activated carbon adsorption; sand filtration; detoxification; postharvest fungicides; imazalil; fludioxonil

\section{Introduction}

Tertiary treatment systems are based on the application of a wide range of physical and chemical methods to completely remove various recalcitrant pollutants from activated sludge secondary effluents $[1,2]$. Physical methods include sand filtration, ultrafiltration (UF), nanofiltration (NF), desalination (reverse osmosis) and activated carbon (AC) adsorption [3], while coagulation and flocculation, ultraviolet disinfection, ozonation, photocatalysis and other advanced oxidation methods are well-known chemical treatment approaches [4,5]. Sand filtration and activated carbon adsorption are considered eco-friendly approaches, since no chemicals are required to remove the pollutants.

Sand filtration has been recognized as one of the most widely used physical methods in tertiary wastewater treatment, resulting in high suspended solids removal at a low cost [6]. The treatment efficiency depends on the hydraulic loading rate, which varies from 0.05 to $0.4 \mathrm{~m} / \mathrm{h}$ [7]. Previous studies have shown that treatment of secondary effluents with 
a slow sand filtration process results in reduced suspended solids compared with the rapid filtration process $[1,8]$. In addition, the implementation of slow sand filtration reduces the need for backwashing. Thus, the low capital and operating cost as well as the easiness and simplicity of handling and maintenance are the main advantages of slow sand filtration [1].

Over the last few decades, activated carbon adsorption has been widely used in the tertiary treatment of wastewaters $[9,10]$. The advantages of the activated carbon process are the high active area and porosity of the activated carbon and its high adsorption capacity for a wide range of pollutants [11]. Activated carbon can remove low molar mass pollutants $(<300 \mathrm{Da})[12,13]$. Among the various forms of activated carbon, granular activated carbon (GAC) is the most common type used for the tertiary treatment of municipal [13] and industrial [14] wastewaters. The effectiveness of adsorption depends on the GAC's specific sorption capacity, the dose and the chemical properties of the activated carbon and the composition of the effluents $[10,15]$.

Activated carbon adsorption processes effectively remove recalcitrant and toxic compounds, including heavy metals [16], alkylphenols, bisphenol A [17], aromatic hydrocarbons $[18,19]$, pharmaceuticals $[20,21]$ and pesticides [14] from wastewaters. However, it was only recently that activated carbon adsorption processes were applied for removing fungicides from agro-industrial effluents [22,23]. Crini et al. [23] reported removal efficiencies of triazole fungicides greater than $99 \%$ by filtration through both powder and granular activated carbon. Sarker et al. [24] reported high adsorption efficiency of benzotriazole and benzimidazole in three different types of activated carbon.

The quality of the discharged effluents of industrial wastewater treatment plants must comply with EU wastewater regulations, whereby residual toxic, bio-accumulative or persistent pollutants, such as fungicides, must be removed [25]. This goal is often achieved through the design and implementation of effective tertiary treatment methods, enabling the safe discharge of treated effluents in natural water bodies. Fruit-packing industries generate wastewaters characterized by high levels of fungicides, with fludioxonil, imazalil and thiabendazole being the most common fungicides used in this sector. These fungicides are used to protect fruits like citrus, pomes, bananas and berries from infections at the postharvest level caused by plant pathogens, such as Alternaria, Botrytis and Penicillium spp. [26,27]. The concentration of these fungicide-rich effluents could range from 20 to $100 \mathrm{mg} / \mathrm{L}$ [28], while their initial concentration levels in the solutions used for treatment of fruits are $200 \mathrm{mg} / \mathrm{L}$ and above. Apart from the demanding biological treatment methods that should be applied for the depuration of such wastewaters, their discharge effluents should be further treated at the tertiary level to remove residual pesticides and therefore meet the legislation limits.

Moreover, tertiary treatment systems can boost irrigated agriculture, reducing YJR water footprint and ameliorating the environmental impact of wastewater disposal [29]. Such treatment approaches can be considered useful tools to meet the criteria enacted by EU regulation 2020/741 regarding irrigation uses of treated wastewaters [30]. Thus, the implementation of low-cost and high-efficiency tertiary treatment methods, like sand filtration and activated carbon adsorption, can allow direct environmental discharge or irrigation uses of the fungicide-rich wastewaters generated by the fruit-packing industry.

In this study, a treatment system consisting of sand filtration and activated carbon adsorption column is evaluated as a tertiary treatment system for the removal of residual imazalil and fludioxonil concentrations from the biologically treated effluents of a fruitpackaging plant.

\section{Materials and Methods}

\subsection{Description of the Sand Filter-Activated Carbon Column System}

A laboratory-scale sand filter and an activated carbon column of a $5 \mathrm{~L}$ working volume each were installed and operated in series for the tertiary treatment of biologically treated wastewater containing residual concentrations of fludioxonil and imazalil (Figure 1). The sand and activated carbon columns were cylindrical and made of opaque plexiglass. Each 
column had a $14 \mathrm{~cm}$ internal diameter and $30 \mathrm{~cm}$ usable height. The sand filter was filled with $4 \mathrm{~cm}$ of gravel on the bottom and $26 \mathrm{~cm}$ of quartz sand above the gravel layer. The AC column was filled successively from the bottom to the top with gravel (4 cm in height), quartz sand (3 cm in height) and granular activated carbon $(23 \mathrm{~cm}$ in height). In the sand column, the secondary effluent was moved downward, and the treated filtrate was directed from the bottom to the top of the activated carbon column.

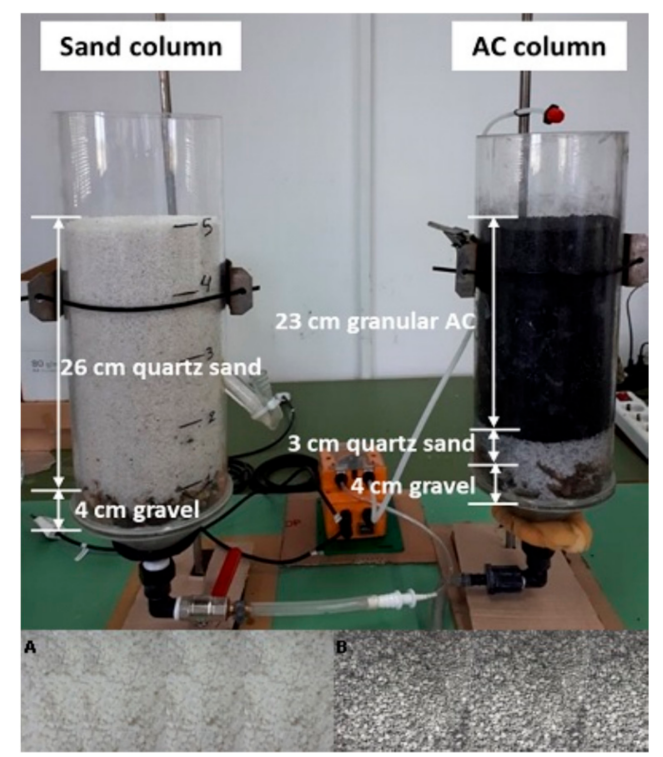

Figure 1. The laboratory-scale sand-activated carbon (AC) system consisting of quartz sand (A) and granular AC (B) used for the tertiary treatment and detoxification of a biologically treated fungicide-containing wastewater.

\subsection{Sorbent Materials and Operating Conditions}

Quartz fine sand and granular activated carbon SILCARBON K835 were used as the filter and sorbent materials and were purchased from SIBELCO Filcom BV and TEMAC company, respectively. Their physicochemical properties are presented in Table 1 . The organic and other contaminant adsorption of the granular AC SILCARBON K835 was higher than any commercial carbon due to the combination of a high bulk density and the large internal surface area. The filtration and adsorption processes were performed at $22{ }^{\circ} \mathrm{C}$.

Table 1. Physicochemical properties of quartz sand and granular activated carbon.

\begin{tabular}{cccc}
\hline Parameter & Quartz Sand & Parameter & Granular AC \\
\hline Grain shape & Sub-angular & Bulk density & $500 \pm 25 \mathrm{~kg} / \mathrm{m}^{3}$ \\
Aqueous solution $\mathrm{pH}$ & $5-8$ & Effective size & $1.2-2.2 \mathrm{~mm}$ \\
Relative density & $2-3 \mathrm{~g} / \mathrm{cm}^{3}$ & Ash content & $<5 \%$ \\
Melting point & $>1610{ }^{\circ} \mathrm{C}$ & Iodine number & $1050 \mathrm{mg} / \mathrm{g} \mathrm{min}$ \\
Effective size & $2-3.5 \mathrm{~mm}$ & Surface area & $1050 \mathrm{~m}^{2} / \mathrm{g}$ \\
Color & White & Dechlorination half-value length & $<5 \mathrm{~cm}$ \\
Content & $96 \% \mathrm{SiO}_{2}$ & Hardness & $98 \%$ \\
Respirable quartz & $<1 \%$ & Activation method & Steam \\
Solubility in water & Negligible & Humidity & $5 \%$ \\
\hline
\end{tabular}

The sand filtration-activated carbon adsorption system was operated under the batch mode, and analyses of five (5) individual samples of $15 \mathrm{~L}$ each were carried out, corresponding to 25 bed volumes in total. During system operation, the hydraulic loading rate was set at 0.024 and $0.016 \mathrm{~m} / \mathrm{h}$ for the sand and activated carbon column, respectively. 
The sand and activated carbon were washed with distilled water prior to filtration of the biologically treated fungicide-containing wastewater. Due to the low concentration of suspended solids in the biologically treated effluent, no clog-up or deposit formation of sand or the AC column occurred during infiltration.

\subsection{Analytical Methods and Phytotoxicity Test}

To evaluate the performance of the tertiary filtration processes, all physicochemical parameters were determined according to the "Standard Methods for the Examination of Water and Wastewater" [31]. The $\mathrm{pH}$ and electrical conductivity (EC) were determined by using a Hanna HI 98191 pH meter and a Crison CM35 conductivity meter, respectively. The concentrations of the total Kjeldahl nitrogen (TKN) and ammonium nitrogen $\left(\mathrm{NH}_{4}{ }^{+}-\mathrm{N}\right)$ were assessed by employing the Kjeldahl and steam distillation methods, respectively, whereas the nitrates and nitrites were estimated through filtration in a Cd-copperized column and colorimetric estimation of the absorbance at $453 \mathrm{~nm}$ by using a sulfanilamide/(1naphthyl) ethylenediamine-dihydrochloride indicator [31]. The turbidity was estimated in the activated carbon permeate by using a Hach 2100 Q IS portable turbidimeter. Escherichia coli counts were determined after $0.45-\mu \mathrm{m}$ filtration of $100 \mathrm{~mL}$ of activated carbon permeate and incubation of the membrane filter culture on Chromocult Coliform Agar plates at $44^{\circ} \mathrm{C}$ for $24 \mathrm{~h}$.

The determination of the fungicides' imazalil and fludioxonil was performed in an HPLC-PDA system (ECOM, Czech Republic) equipped with a C18 $250 \times 4.6 \mathrm{~mm}$ column (Fortis, UK), where acetonitrile $/ \mathrm{H}_{2} \mathrm{O} 75: 25, v / v$ was used as the mobile phase at a constant flow rate of $0.8 \mathrm{~mL} / \mathrm{min}$ [32]. The fungicides' concentrations were determined via an external calibration curve constructed by analysis of a series of standard solutions of the two analytes. The limits of detection and quantification were 0.25 and $0.5 \mathrm{mg} / \mathrm{L}$, respectively, for both fungicides, and the method showed linearity in a concentration range of $0.5-20 \mathrm{mg} / \mathrm{L}$ ( $\mathrm{R}^{2}$ of 0.9977 and 0.9993 for fludioxonil and imazalil, respectively).

The seed germination index (GI) was used as an estimation of the reduction in the toxicity of the treated effluents. Hence, the biologically treated fungicide-containing effluent, either undiluted or diluted at 1:1 v/v, the sand filtration and the activated carbon-treated effluents were used to determine the seed GI. In particular, a total of 25 organic tomato seeds were placed in a Petri dish containing three layers of filter paper and moistened with the biologically treated fungicide-containing effluent, the sand or the activated carbon permeate, as appropriate. The GI was estimated under the tested experimental setups after 5 days of incubation at $24^{\circ} \mathrm{C}$.

\subsection{Wastewater Characteristics}

The sand column was first fed with biologically treated fungicide-containing wastewater derived from the effluent of a fixed-bed bioreactor, while the activated carbon column was fed with the filtrate obtained from the sand column. Each column was evenly fed once in every cycle of experiments. The main physicochemical characteristics of the biologically treated fungicide-containing wastewater were as follows: total chemical oxygen demand (COD), $209 \pm 4.3 \mathrm{mg} / \mathrm{L}$; soluble COD, $181 \pm 5.6 \mathrm{mg} / \mathrm{L}$; 5-day biochemical oxygen demand $\left(\mathrm{BOD}_{5}\right), 2 \mathrm{mg} / \mathrm{L} ; \mathrm{pH}, 6.8 \pm 0.01 ; \mathrm{EC}, 4.06 \pm 0.01 \mathrm{mS} / \mathrm{cm}$; total suspended solids, $24 \pm 2 \mathrm{mg} / \mathrm{L}$; TKN, $7.65 \pm 0.19 \mathrm{mg} / \mathrm{L}$ and $\mathrm{NH}_{4}{ }^{+}-\mathrm{N}, 1.77 \pm 0.09 \mathrm{mg} / \mathrm{L}$. No nitrates or nitrites were detected in the biologically treated fungicide-containing wastewater. The total nitrogen (TN) was determined as the sum of the TKN, $\mathrm{NO}_{3}{ }^{-}-\mathrm{N}$ and $\mathrm{NO}_{2}{ }^{-}$$\mathrm{N}$ concentrations. The biologically treated fungicide-containing wastewater contained $41.3 \pm 0.04 \mathrm{mg} / \mathrm{L}$ of imazalil and $7.4 \pm 0.43 \mathrm{mg} / \mathrm{L}$ of fludioxonil.

\subsection{Statistical Analyses}

Analysis of variance (ANOVA), using Ducan's multiple range test, was conducted to identify statistically significant differences in the pollutant parameters and in the germination indices prior to and after sand filtration and activated carbon adsorption. The 
Student's $t$-test at $p<0.05$ or $p<0.01$ was employed to evaluate the removal efficiencies after sand filtration and activated carbon adsorption.

\section{Results and Discussion}

3.1. Evaluation of the Tertiary Treatment System's Ability to Remove Macronutrients from the Biologically Treated Fungicide-Containing Effluent

Regarding the removal of organic matter, the total COD was significantly reduced from $209 \pm 4.3 \mathrm{mg} / \mathrm{L}$ in the biologically treated fungicide-containing wastewater to $177 \pm 2.1 \mathrm{mg} / \mathrm{L}$ and $49.1 \pm 2.1 \mathrm{mg} / \mathrm{L}$ in the permeate of the sand filter and activated carbon column, respectively (Figure 2). Moreover, the soluble COD was significantly decreased from $181 \pm 5.64 \mathrm{mg} / \mathrm{L}$ in the biologically treated effluent to $151 \pm 2.1 \mathrm{mg} / \mathrm{L}$ in the sand filtrate, whereas the respective value in the permeate of the activated carbon absorbent was extremely low $(21.3 \pm 2.1 \mathrm{mg} / \mathrm{L}$ (Figure 2)). Both the total and soluble COD removal efficiencies in the sand filter were similar and relatively low, being equal to $15.3 \pm 1.5 \%$ and $16.4 \pm 1.8 \%$, respectively (Figure 2 ). However, the COD was effectively removed in the activated carbon column, showing total and soluble COD removal efficiencies of $76.5 \pm 1.5 \%$ and $88.2 \pm 1.3 \%$, respectively (Figure 2). Reynoso Varela et al. [33] reported an improvement of COD removal during the addition of granular activated carbon in the mixed liquor of a sequence batch reactor (SBR) system treating wastewater containing $4 \mathrm{mg} / \mathrm{L}$ endosulfan. The highest COD removal efficiency was clearly observed in the activated carbon column treatment. This indicates the high contribution of activated carbon to the removal of organic load compared with that of the sand filter. Mohammad-pajooh et al. [34] reported COD removal efficiencies of up to $75 \%$ after adsorption of treated landfill leachate in the granular activated carbon. On the other hand, the removal of dissolved organic carbon by approximately $16 \%$ in the sand filter may be attributed to the slow hydraulic loading rate applied [7]. Moreover, the total suspended solids (TSS) were equal to 24 and $22 \mathrm{mg} / \mathrm{L}$ in the biologically treated wastewater and the sand filtrate, respectively, which were then reduced greatly to $4 \mathrm{mg} / \mathrm{L}$ in the activated carbon permeate, complying with the threshold limit for unrestricted irrigation (EU regulation 2020/741) [30]. In addition, the turbidity in the activated carbon permeate was $1.55 \pm 0.03 \mathrm{FNU}$ (formazin nephelometric units), meeting the legislation limit set by EU regulation 2020/741. No E. coli was detected in the permeate of the activated carbon column.

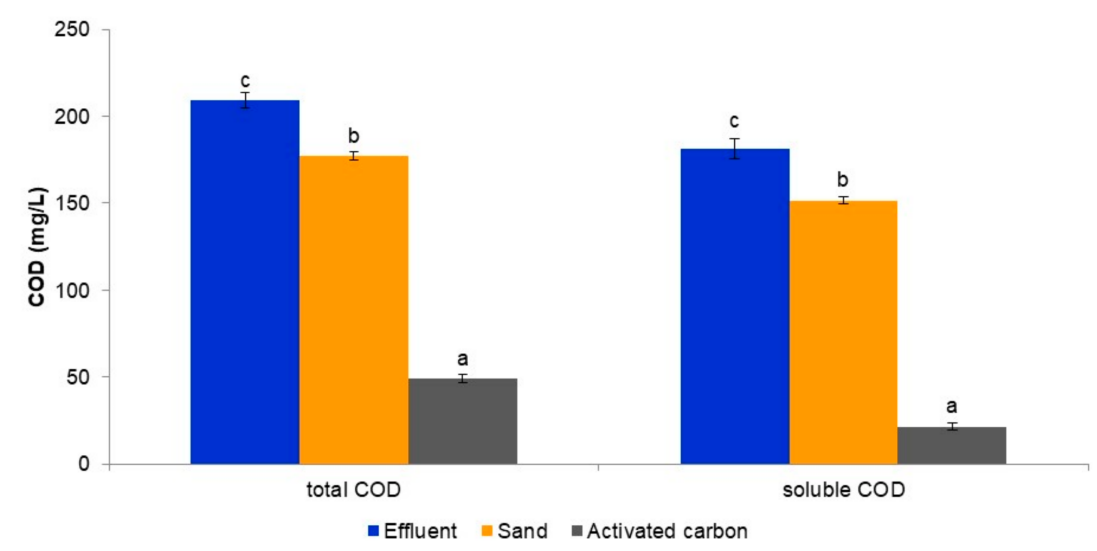

Figure 2. Total and soluble COD concentrations during processing of the biologically treated fungicide-containing effluent through the sand filter and the activated carbon adsorption column system. For each measured parameter, bars designated by the same letter are not significantly different at the $5 \%$ level.

The high electrical conductivity value of the biologically treated fungicide-containing effluent was due to the addition of a salt and trace element solution in the fungicidecontaining wastewater, which was initially treated in a fixed-bed bioreactor. Both the $\mathrm{pH}$ 
and EC were not significantly altered by sand filtration, although changes in these parameters were recorded in the permeate of the activated carbon column (Figure 3). In particular, the $\mathrm{pH}$ was significantly increased from $6.75 \pm 0.01$ in the biologically treated fungicidecontaining wastewater and the sand filtrate to $7.22 \pm 0.04$ in the activated carbon permeate. The $\mathrm{pH}$ rise can be attributed to the interaction of the anions of the wastewater and the activated carbon surface through the performance of an ion exchange type phenomenon, where activated carbon adsorbs anions after surface protonation [35]. In an opposite manner, the EC remained unchanged after sand filtration, whereas the EC values were significantly reduced from $3.98 \pm 0.07 \mathrm{mS} / \mathrm{cm}$ in the sand filtrate to $3.22 \pm 0.21 \mathrm{mS} / \mathrm{cm}$ in the activated carbon permeate due to ion adsorption.

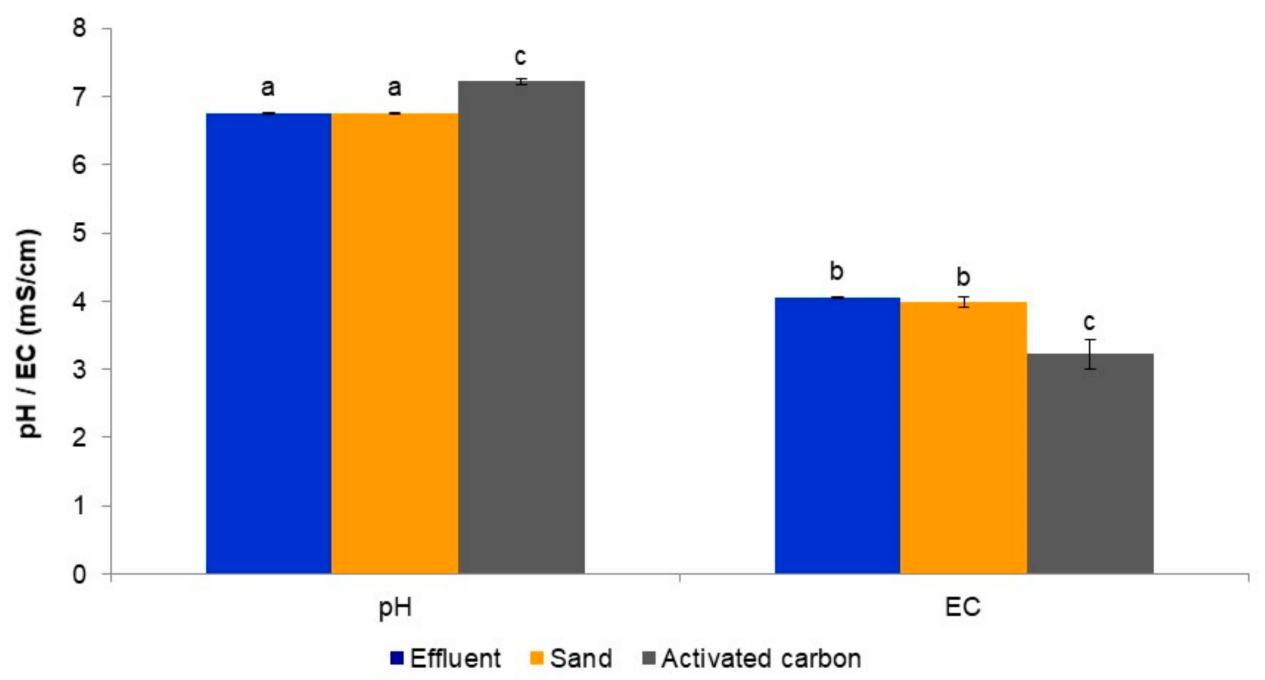

Figure 3. The $\mathrm{pH}$ and electrical conductivity (EC) changes during processing of the biologically treated fungicide-containing effluent through the sand filter and the activated carbon adsorption column system. For each parameter, bars designated by the same letter are not significantly different at the $5 \%$ level.

No effect of sand filtration on the removal of nitrogenous compounds is observed in Figure 4. However, the organic nitrogen content was effectively removed by decreasing the TKN concentration from $7.65 \pm 0.19 \mathrm{mg} / \mathrm{L}$ and $7.09 \pm 0.09 \mathrm{mg} / \mathrm{L}$ in the biologically treated wastewater and the sand filtrate, respectively, to $2.33 \pm 0.09 \mathrm{mg} / \mathrm{L}$ in the activated carbon permeate. Nitrate- $\mathrm{N}$ was reduced from $0.31 \pm 0.02 \mathrm{mg} / \mathrm{L}$ in the biologically treated effluent to $0.10 \pm 0.01 \mathrm{mg} / \mathrm{L}$ in the permeate after activated carbon adsorption. Sand slightly contributed to nitrogen content removal (i.e., by $5.25 \pm 1.75 \%$ ), whereas the total nitrogen removal reached $69.18 \pm 2.03 \%$ after activated carbon adsorption. The statistically significant increase of the negligible $\mathrm{NO}_{3}{ }^{-}-\mathrm{N}$ concentration in the sand filtrate may be attributed to the low activity of nitrifying microbiota immobilized in the sand. This is also supported by the respective decrease in $\mathrm{NH}_{4}{ }^{+}-\mathrm{N}$ concentration in the sand filtrate. On the other hand, the $\mathrm{NH}_{4}{ }^{+}-\mathrm{N}$ concentration was reduced below $1 \mathrm{mg} / \mathrm{L}$ in the activated carbon column. 

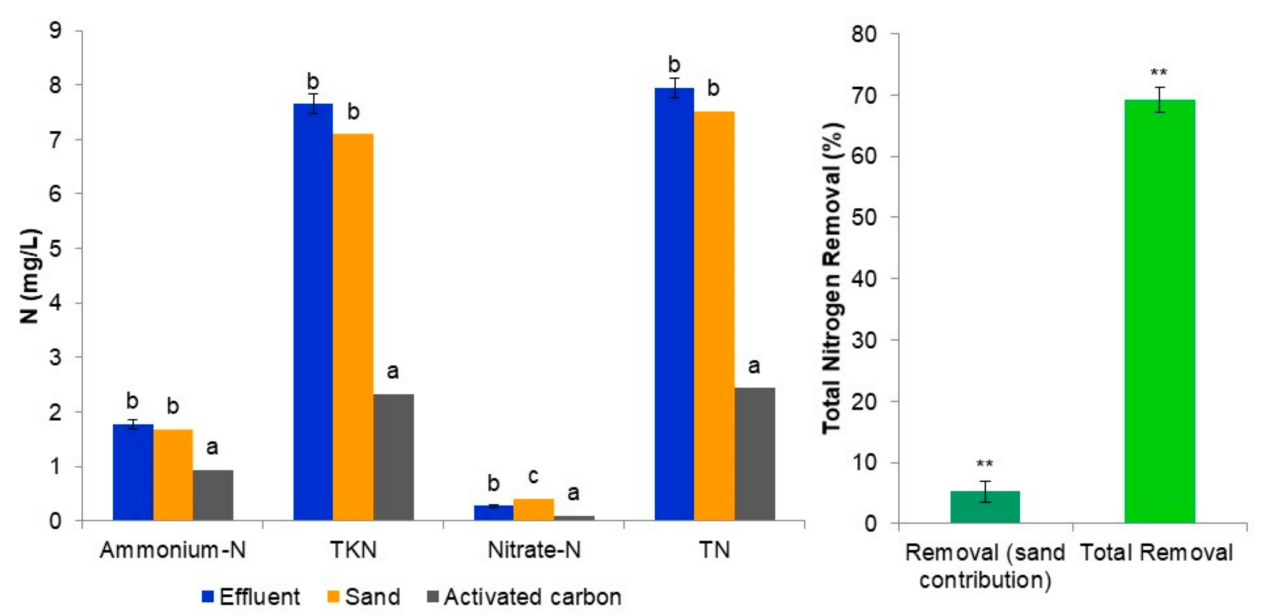

Figure 4. Changes in the concentrations of different nitrogen forms $\left(\mathrm{NH}_{4}{ }^{+}-\mathrm{N}, \mathrm{TKN}, \mathrm{NO}_{3}{ }^{-}-\mathrm{N}\right.$, total Kjeldahl nitrogen) (left graph) and removal levels (right graph) during processing of the biologically treated fungicide-containing effluent through the sand filter and the activated carbon adsorption column system. For each measured parameter, bars designated by the same letter are not significantly different at the $5 \%$ level. Asterisks indicate statistically significant differences at the $1 \%$ level regarding the total nitrogen (TN) removal efficiency after sand filtration and the sand filtration-activated carbon adsorption process.

3.2. Evaluation of the Tertiary Treatment System's Ability to Remove Imazalil and Fludioxonil from the Biologically Treated Fungicide-Containing Effluent

The imazalil concentration in the biologically treated wastewater was reduced from $41.26 \pm 0.04 \mathrm{mg} / \mathrm{L}$ to $32.24 \pm 1.73 \mathrm{mg} / \mathrm{L}$ upon slow sand filtration (removal efficiency of $21.9 \pm 4.11 \mathrm{mg} / \mathrm{L}$ ), and it was finally fully removed (residue below the limit of detection) in the activated carbon permeate (Figure 5). No statistically significant differences were observed in the concentration of fludioxonil between the biologically treated wastewater and the sand filtrate, whereas activated carbon resulted in the removal of this fungicide by $87.40 \pm 4.14 \%$, detecting a residual concentration below $1 \mathrm{mg} / \mathrm{L}$. However, the increase in the contact time between the wastewater and the activated carbon may favor the adsorption capacity over time. A strong correlation was observed between the total and soluble COD and the concentration of imazalil or fludioxonil $(p<0.05)$. Activated carbon has been reported to optimally remove basic pesticides at a $\mathrm{pH}$ near their dissociation constant (e.g., near pH 6.5 in the case of imazalil). However, recent findings suggest that the highest adsorption capabilities are recorded in more alkaline $\mathrm{pH}$ for carbonaceous sorption materials [36], as was also verified in the current study for the imazalil concentration. On the other hand, the dissociation constants of fludioxonil highly deviated from the neutral $\mathrm{pH}$, a fact that influenced the removal efficiency of this fungicide in the activated carbon column. 

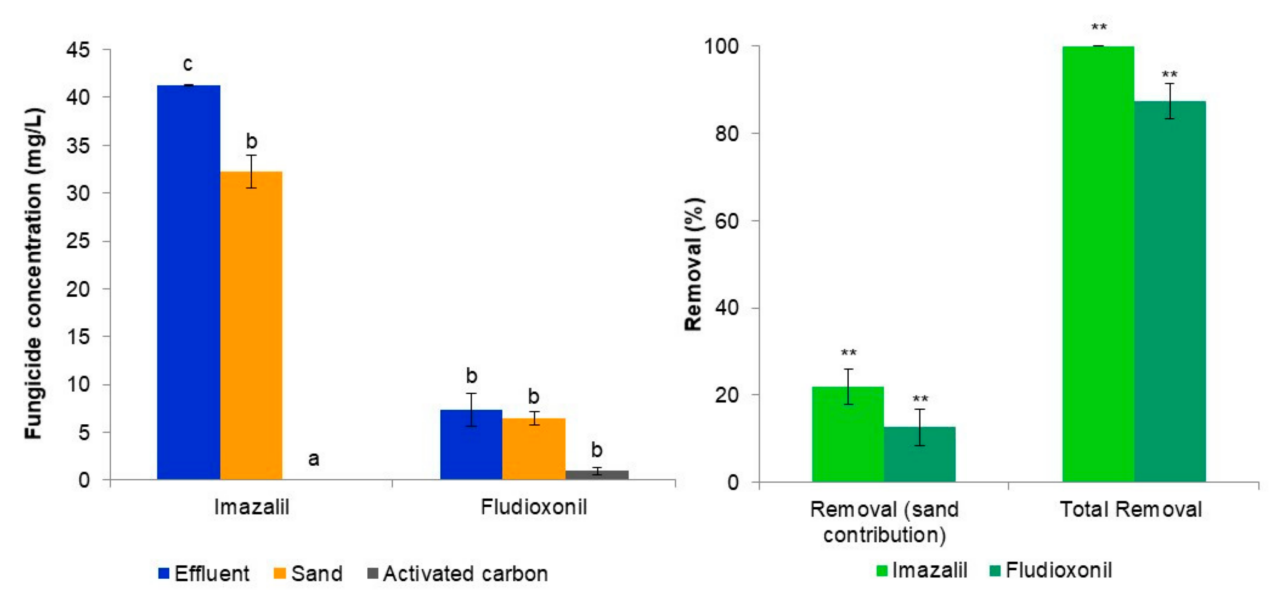

Figure 5. Imazalil and fludioxonil concentrations (left graph) and their removal efficiencies (right graph) during processing of the biologically treated fungicide-containing effluent through the sand filter and the activated carbon adsorption column system. For each pesticide, bars designated by the same letter are not statistically significant at the $5 \%$ level. Asterisks indicate statistically significant differences at the $1 \%$ level regarding fungicide removal efficiencies after the sand filtration and sand filtration-activated carbon adsorption process.

Regarding pesticide removal, activated carbon was identified as the best absorbent at the first eluted pore volumes, resulting in the complete removal of $30 \mu \mathrm{M}$ of thiophanatemethyl [37]. Moreover, activated carbon performed better than ozonation during posttreatment of the effluent of an MBR, processing wastewater that contained the pesticides 2,4$\mathrm{D}$, atrazine, carbendazim and diuron [38]. Interestingly, the activated carbon's performance was even better than that of reverse osmosis during removal of the above-mentioned pesticides from the effluent of this MBR system [38]. Moreover, the adsorption capability of the activated carbon was higher compared with that of common sorption materials like sand during the removal of micropollutants, including imazalil, in a constructed wetland system [39]. Martín-González et al. [40] found that activated carbon could optimally adsorb imazalil sulphate at concentration of $100 \mathrm{mg} / \mathrm{L}$ and a neutral $\mathrm{pH}$. The use of activated carbon resulted in the effective removal of six pesticides commonly applied in viticulture, including imazalil [41]. In particular, the use of activated carbon as a fining agent resulted in the complete removal of imazalil from white wine. Despite this previous research on the efficiency of activated carbon for removing imazalil from wastewaters and other effluents, this is the first report that shows the high sorption affinity of activated carbon leading to the efficient removal of fludioxonil from biologically treated agro-industrial wastewater. Regarding fludioxonil sorption in other industrial applications, the fludioxonil removal efficiency was determined to be $90 \%$ during clarification of red wine with charcoal, which is similar to that reported in the current study $(87.40 \pm 4.14 \%)$ [42].

\subsection{Detoxification of the Biologically Treated Fungicide-Containing Effluent in the Sand Filtration-Activated Carbon Adsorption System}

Germination tests were carried out using either undiluted or 1:1 $v / v$ diluted biologically treated wastewater, sand filtrate and activated carbon permeate (Figure 6). Sand filtration showed no significant contribution in the detoxification of the biologically treated fungicide-containing wastewater. However, activated carbon adsorption resulted in the attenuation of effluent phytotoxicity by increasing the GI from $1.51 \pm 1.06 \%$ in the undiluted biologically treated wastewater to $48.00 \pm 6.29 \%$ after activated carbon adsorption. Further attenuation of the toxicity was observed for the 1:1 $v / v$ diluted effluent, where the GI raised significantly from $12.4 \pm 1.94 \%$ prior to sand filtration to $79.77 \pm 9.30 \%$ after activated carbon adsorption. Moreover, the rise in $\mathrm{pH}$ highly contributed to the improvement of the GI in both the diluted and undiluted effluents $(p<0.01)$. Rott et al. [43] reported that powdered activated carbon resulted in the detoxification of a pesticide-containing wastew- 
ater. In addition, sediment contaminated with hexachlorobenzene and lindane could be effectively detoxified with activated carbon treatment [44]. The toxicity, as estimated by duckweed tests, was attenuated by at least 10-15\% during photocatalytic treatment of a $15 \mathrm{mg} / \mathrm{L}$ imazalil sulphate solution using $\mathrm{TiO}_{2}$ containing 7\% activated carbon instead of using titania alone [45].

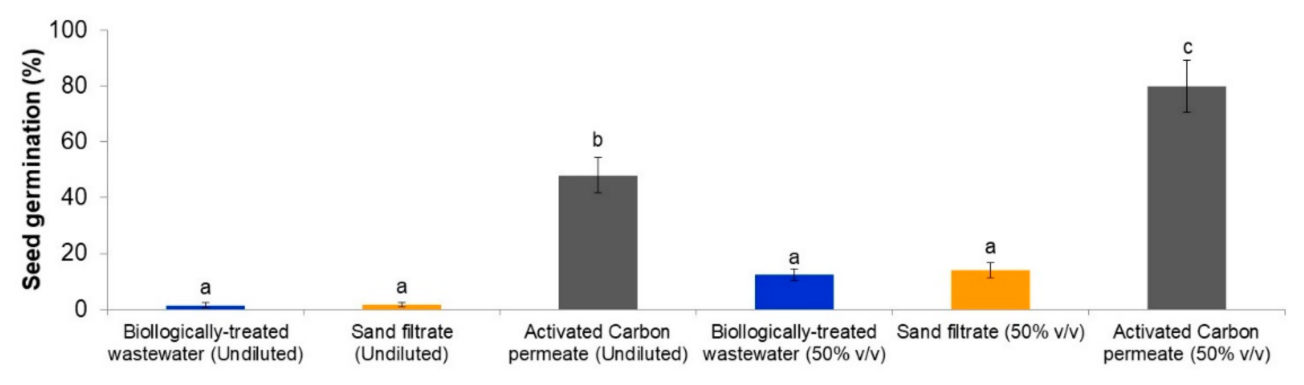

Figure 6. The germination index (GI) values of the biologically treated fungicide-containing effluent, either undiluted or diluted by $50 \%$, before and after treatment through the sand filter and the activated carbon adsorption column system. Bars designated by the same letter are not statistically different at the $5 \%$ level.

\section{Conclusions}

Evaluation of a tertiary treatment system composed of sand filtration and activated carbon treatment clearly showed the greater contribution of the former process in the removal of macronutrients, biosolids and pesticides from a biologically treated agro-industrial effluent. This tertiary treatment led to a significant reduction of the total COD levels $\left(<50 \mathrm{mg} / \mathrm{L}\right.$ ), EC, total nitrogen (from $7.94 \pm 0.02 \mathrm{mg} / \mathrm{L}$ to $2.44 \pm 0.02 \mathrm{mg} / \mathrm{L}$ ) and $\mathrm{NH}_{4}{ }^{+}-\mathrm{N}$ $(<1 \mathrm{mg} / \mathrm{L})$, resulting in the production of high-quality treated effluents complying with the guidelines recommended for Mediterranean countries regarding effluent discharge, as well as with the limits enacted by Greek Joint Ministerial Decree 145116/11. In addition, the tertiary treatment employed, and especially activated carbon adsorption, achieved the complete removal of imazalil, partial but still significant removal of fludioxonil and a significant detoxification of the biologically treated fungicide-containing effluent. Overall, the tertiary treatment employed, and activated carbon filtration in particular, showed high potential to drastically reduce the organic and inorganic load of secondary biologically treated effluents from fruit-packaging plants, enabling their direct environmental discharge or recycling in primary agricultural production as irrigation water.

Author Contributions: K.A. performed the physicochemical and chromatographic analysis; K.A. and Z.M. performed the phytotoxicity assay and collected the biologically treated effluent; K.A., D.G.K., S.N. and P.M. interpreted the data; K.A., S.N. and P.M. drafted the paper; S.N. and P.M. supervised the work. All authors have read and agreed to the published version of the manuscript.

Funding: This research, carried out within the frame of the research project entitled "Development and implementation of novel biobased methods for the treatment of pesticide-contaminated wastewaters from agro-industries, MIS 5030360", has been co-financed by the European Regional Development Fund of the European Union and Greek national funds through the Operational Program Competitiveness, Entrepreneurship and Innovation, under the call RESEARCH-CREATE-INNOVATE (project code: T1EDK-02566).

Institutional Review Board Statement: Not applicable.

Informed Consent Statement: Not applicable.

Conflicts of Interest: The authors declare no conflict of interest. 


\section{References}

1. Langenbach, K.; Kuschk, P.; Horn, H.; Kästner, M. Slow sand filtration of secondary clarifier effluent for wastewater reuse. Environ. Sci. Technol. 2009, 43, 5896-5901. [CrossRef] [PubMed]

2. Foo, K.Y.; Hameed, B.H. Detoxification of pesticide waste via activated carbon adsorption process. J. Hazard. Mater. 2010, 175, 1-11. [CrossRef] [PubMed]

3. Melgarejo, J.; Prats, D.; Molina, A.; Trapote, A. A case study of urban wastewater reclamation in Spain: Comparison of water quality produced by using alternative processes and related costs. J. Water Reuse Desalin. 2016, 6, 72-81. [CrossRef]

4. Matamoros, V.; Salvadó, V. Evaluation of a coagulation/flocculation-lamellar clarifier and filtration-UV-chlorination reactor for removing emerging contaminants at full-scale wastewater treatment plants in Spain. J. Environ. Manag. 2013, 117, 96-102. [CrossRef] [PubMed]

5. Arzate, S.; Pfister, S.; Oberschelp, C.; Sánchez-Pérez, J.A. Environmental impacts of an advanced oxidation process as tertiary treatment in a wastewater treatment plant. Sci. Total Environ. 2019, 694, 133572. [CrossRef] [PubMed]

6. Hamoda, M.F.; Al-Ghusain, I.; AL-Mutairi, N.Z. Sand filtration of wastewater for tertiary treatment and water reuse. Desalination 2004, 164, 203-211. [CrossRef]

7. Kader Yettefti, I.; Aboussabiq, F.; Etahiri, S.; Mountadar, M.; Assobhei, O. Performance evaluation of sand filter for tertiary treatment of secondary effluent of wastewater: Effect of hydraulic loading. Phys. Chem. News 2013, 68, 106-113.

8. Sadiq, R.; Husain, T.; Al-Zahrani, A.M.; Sheikh, A.K.; Farooq, S. Secondary effluent treatment by slow sand filters: Performance and risk analysis. Water Air Soil Pollut. 2003, 143, 41-63. [CrossRef]

9. Jamil, S.; Loganathan, P.; Listowski, A.; Kandasamy, J.; Khourshed, C.; Vigneswaran, S. Simultaneous removal of natural organic matter and micro-organic pollutants from reverse osmosis concentrate using granular activated carbon. Water Res. 2019, 155, 106-114. [CrossRef]

10. Zusman, O.B.; Kummel, M.L.; De la Rosa, J.M.; Mishael, Y.G. Dissolved organic matter adsorption from surface waters by granular composites versus granular activated carbon columns: An applicable approach. Water Res. 2020, 181, 115920. [CrossRef]

11. Guillossou, R.; Le Roux, J.; Mailler, R.; Vulliet, E.; Morlay, C.; Nauleau, F.; Gasperi, J.; Rocher, V. Organic micropollutants in a large wastewater treatment plant: What are the benefits of an advanced treatment by activated carbon adsorption in comparison to conventional treatment? Chemosphere 2019, 218, 1050-1060. [CrossRef]

12. Boehler, M.; Zwickenpflug, B.; Hollender, J.; Ternes, T.; Joss, A.; Siegrist, H. Removal of micropollutants in municipal wastewater treatment plants by powder-activated carbon. Water Sci. Technol. 2012, 66, 2115-2121. [CrossRef]

13. Benstoem, F.; Nahrstedt, A.; Boehler, M.; Knopp, G.; Montag, D.; Siegrist, H.; Pinnekamp, J. Performance of granular activated carbon to remove micropollutants from municipal wastewater-A meta-analysis of pilot- and large-scale studies. Chemosphere 2017, 185, 105-118. [CrossRef]

14. Tang, L.; Ma, X.Y.; Wang, Y.; Zhang, S.; Zheng, K.; Wang, X.C.; Lin, Y. Removal of trace organic pollutants (pharmaceuticals and pesticides) and reduction of biological effects from secondary effluent by typical granular activated carbon. Sci. Total Environ. 2020, 749, 141611. [CrossRef]

15. Kårelid, V.; Larsson, G.; Björlenius, B. Pilot-scale removal of pharmaceuticals in municipal wastewater: Comparison of granular and powdered activated carbon treatment at three wastewater treatment plants. J. Environ. Manag. 2017, 193, 491-502. [CrossRef]

16. Shahrokhi-Shahraki, R.; Benally, C.; El-Din, M.G.; Park, J. High efficiency removal of heavy metals using tire-derived activated carbon vs commercial activated carbon: Insights into the adsorption mechanisms. Chemosphere 2021, 264, 128455. [CrossRef] [PubMed]

17. Mailler, R.; Gasperi, J.; Coquet, Y.; Buleté, A.; Vulliet, E.; Deshayes, S.; Zedek, S.; Mirande-Bret, C.; Eudes, V.; Bressy, A.; et al. Removal of a wide range of emerging pollutants from wastewater treatment plant discharges by micro-grain activated carbon in fluidized bed as tertiary treatment at large pilot scale. Sci. Total Environ. 2016, 542, 983-996. [CrossRef] [PubMed]

18. Liu, J.; Chen, J.; Jiang, L.; Yin, X. Adsorption of mixed polycyclic aromatic hydrocarbons in surfactant solutions by activated carbon. J. Ind. Eng. Chem. 2014, 20, 616-623. [CrossRef]

19. Lamichhane, S.; Bal Krishna, K.C.; Sarukkalige, R. Polycyclic aromatic hydrocarbons (PAHs) removal by sorption: A review. Chemosphere 2016, 148, 336-353. [CrossRef] [PubMed]

20. Bhadra, B.N.; Seo, P.W.; Jhung, S.H. Adsorption of diclofenac sodium from water using oxidized activated carbon. Chem. Eng. J. 2016, 301, 27-34. [CrossRef]

21. Costa, L.R.D.C.; Féris, L.A. Use of functionalized adsorbents for tetracycline removal in wastewater: Adsorption mechanism and comparison with activated carbon. J. Environ. Sci. Health A 2020, 55, 1604-1614. [CrossRef] [PubMed]

22. Crini, G.; Exposito Saintemarie, A.; Rocchi, S.; Fourmentin, M.; Jeanvoine, A.; Millon, L.; Morin-Crini, N. Simultaneous removal of five triazole fungicides from synthetic solutions on activated carbons and cyclodextrin-based adsorbents. Heliyon 2017, 3 , e00380. [CrossRef] [PubMed]

23. Morin-Crini, N.; Rocchi, S.; Jeanvoine, A.; Garcia, C.; Millon, L.; Crini, G. Analysis of triazole fungicides in aqueous solutions and their removal on modified activated carbons. Arab. J. Sci. Eng. 2017, 43, 3493-3501. [CrossRef]

24. Sarker, M.; Bhadra, B.N.; Seo, P.W.; Jhung, S.H. Adsorption of benzotriazole and benzimidazole from water over a Co-based metal azolate framework MAF-5(Co). J. Hazard. Mater. 2017, 324, 131-138. [CrossRef] [PubMed] 
25. Kosek, K.; Luczkiewicz, A.; Fudala-Książek, S.; Jankowska, K.; Szopińska, M.; Svahn, O.; Tränckner, J.; Kaiser, A.; Langas, V.; Björklund, E. Implementation of advanced micropollutants removal technologies in wastewater treatment plants (WWTPs) Examples and challenges based on selected EU countries. Environ. Sci. Policy 2020, 112, 213-226. [CrossRef]

26. Youssef, K.; Ligorio, A.; Nigro, F.; Ippolito, A. Activity of salts incorporated in wax in controlling postharvest diseases of citrus fruit. Postharvest Biol. Technol. 2012, 65, 39-43. [CrossRef]

27. D'Aquino, S.; Palma, A.; Angioni, A.; Schirra, M. Residue levels and efficacy of fludioxonil and thiabendazole in controlling postharvest green mold decay in citrus fruit when applied in combination with sodium bicarbonate. J. Agric. Food Chem. 2013, 61, 296-306. [CrossRef]

28. Santiago, D.E.; Pastrana-Martínez, L.M.; Pulido-Melián, E.; Araña, J.; Faria, J.L.; Silva, A.M.; Díaz, Ó.G.; Doña-Rodríguez, J.M. $\mathrm{TiO}_{2}$-based $\left(\mathrm{Fe}_{3} \mathrm{O}_{4}, \mathrm{SiO}_{2}\right.$, reduced graphene oxide) magnetically recoverable photocatalysts for imazalil degradation in a synthetic wastewater. Environ. Sci. Pollut. Res. 2018, 25, 27724-27736. [CrossRef]

29. Libutti, A.; Gatta, G.; Gagliardi, A.; Vergine, P.; Pollice, A.; Beneduce, L.; Disciglio, G.; Tarantino, E. Agro-industrial wastewater reuse for irrigation of a vegetable crop succession under Mediterranean conditions. Agric. Water Manag. 2018, 196, 1-14. [CrossRef]

30. Regulation (EU) 2020/741 of the European Parliament and of the Council of 25 May 2020 on Minimum Requirements for Water Reuse (Text with EEA Relevance).Official Journal of the European Union L 177/32. Available online: https:/ / eur-lex.europa.eu/ $\mathrm{eli} / \mathrm{reg} / 2020 / 741 /$ oj (accessed on 2 July 2021).

31. Clesceri, L.S.; Greenberg, A.E.; Eaton, A.D. Standard Methods for the Examination of Water and Wastewater, 20th ed.; American Public Health Association (APHA): Washington, DC, USA, 1998.

32. Mavriou, Z.; Alexandropoulou, I.; Melidis, P.; Karpouzas, D.G.; Ntougias, S. Biotreatment and bacterial succession in an upflow immobilized cell bioreactor fed with fludioxonil wastewater. Environ. Sci. Pollut. Res. 2020, 28, 3774-3786. [CrossRef]

33. Reynoso Varela, A.; Vázquez Contreras, F.P.; de los Santos Villalobos, S.; Alvarez Valencia, L.H.; Ulloa Mercado, R.G.; Serrano Palacios, D. Removal of endosulfan in a sequencing batch reactor: Addition of granular activated carbon as improvement strategy. Water Environ. J. 2021, 35, 390-401. [CrossRef]

34. Mohammad-pajooh, E.; Turcios, A.E.; Cuff, G.; Weichgrebe, D.; Rosenwinkel, K.-H.; Vedenyapina, M.D.; Sharifullina, L.R. Removal of inert COD and trace metals from stabilized landfill leachate by granular activated carbon (GAC) adsorption. J. Environ. Manag. 2018, 228, 189-196. [CrossRef]

35. Farmer, R.W.; Dussert, B.W.; Kovacic, S.L. Improved granular activated carbon for the stabilization of wastewater pH. Am. Chem. Soc. Div. Fuel Chem. 1996, 41, 456-458.

36. García-Jaramillo, M.; Cox, L.; Knicker, H.E.; Cornejo, J.; Spokas, K.A.; Hermosín, M. Characterization and selection of biochar for an efficient retention of tricyclazole in a flooded alluvial paddy soil. J. Hazard. Mater. 2015, 286, 581-588. [CrossRef]

37. Flores, F.M.; Undabeytia, T.; Jaworski, M.; Morillo, E.; Sánchez, R.M.T. Organo-montmorillonites as adsorbent materials for thiophanate-methyl removal: Adsorption-desorption studies and technological applications. J. Environ. Chem. Eng. 2020, 8, 103806. [CrossRef]

38. de Almeida Lopes, T.S.; Heßler, R.; Bohner, C.; Junior, G.B.A.; de Sena, R.F. Pesticides removal from industrial wastewater by a membrane bioreactor and post-treatment with either activated carbon, reverse osmosis or ozonation. J. Environ. Chem. Eng. 2020, 8,104538 .

39. Zhang, L.; Lyu, T.; Vargas, C.A.R.; Arias, C.A.; Carvalho, P.N.; Brix, H. New insights into the effects of support matrix on the removal of organic micro-pollutants and the microbial community in constructed wetlands. Environ. Pollut. 2018, 240, 699-708. [CrossRef] [PubMed]

40. Martín-González, M.A.; González-Díaz, O.; Susial, P.; Araña, J.; Herrera-Melián, J.A.; Doña-Rodríguez, J.M.; Pérez-Peña, J. Reuse of Phoenix canariensis palm frond mulch as biosorbent and as precursor of activated carbons for the adsorption of imazalil in aqueous phase. Chem. Eng. J. 2014, 245, 348-358. [CrossRef]

41. Sen, K.; Cabaroglu, T.; Yilmaz, H. The influence of fining agents on the removal of some pesticides from white wine of Vitis vinifera L. cv. Emir. Food Chem. Toxicol. 2012, 50, 3990-3995. [CrossRef]

42. Fernández, M.J.; Oliva, J.; Barba, A.; Cámara, M.A. Effects of clarification and filtration processes on the removal of fungicide residues in red wines (Var. Monastrell). J. Agric. Food Chem. 2005, 53, 6156-6161. [CrossRef]

43. Rott, E.; Pittmann, T.; Wasielewski, S.; Kugele, A.; Minke, R. Detoxification of pesticide-containing wastewater with FeIII, activated carbon and Fenton reagent and its control using three standardized bacterial inhibition tests. Water 2017, 9, 969. [CrossRef]

44. Grgić, M.; Maletić, S.; Beljin, J.; Isakovski, M.K.; Rončević, S.; Tubić, A.; Agbaba, J. Lindane and hexachlorobenzene sequestration and detoxification in contaminated sediment amended with carbon-rich sorbents. Chemosphere 2019, 220, 1033-1040. [CrossRef] [PubMed]

45. Santiago, D.E.; Pulido Melián, E.; Fernández Rodríguez, C.; Ortega Méndez, J.A.; Pérez-Báez, S.O.; Doña-Rodríguez, J.M. Degradation and detoxification of banana postharvest treatment water using advanced oxidation techniques. Green Sustain. Chem. 2011, 1, 39-46. [CrossRef] 